\title{
Study of phytochemical, antioxidant, antimicrobial and anticancer activity of Berberis aristita
}

\author{
Basanta Lamichhane ${ }^{1}$, Sandeep Adhikari ${ }^{1}$, Pritish Shrestha ${ }^{1}$, Bhupal Govinda Shrestha ${ }^{1 *}$ \\ ${ }^{1}$ Department of Biotechnology, Kathmandu University, Dhulikhel, 6250, Nepal
}

\begin{abstract}
The present study was undertaken to find the phytochemical presence, antioxidant potential, antimicrobial activity, and anticancer activity of methanol extract of Berberis aristita. Plant extract showed the presence of antioxidants like alkaloid, saponin, terpenoids, coumarin, flavonoids, tannin, glycoside and steroid. Further, antioxidant assay like DPPH (Diphenyl-2-picrylhydrazyl) assay, hydrogen peroxide assay and reducing power assay was done. DPPH free radical Scavenging Activity was expressed in \% inhibition with L Ascorbic acid as standard showing IC50 $9.6 \mu \mathrm{g} / \mathrm{ml}$ and that of extract was $33.31 \mu \mathrm{g} / \mathrm{ml}$. Hydrogen peroxide radical scavenging activity was comparable to standard, IC50 for L Ascorbic acid is $54.23 \mu \mathrm{g} / \mathrm{ml}$ and that of B. Aristita is $60.6 \mu \mathrm{g} / \mathrm{ml}$. Similarly, reducing power of plant extract at different concentration was comparable with L-Ascorbic Acid. Antimicrobial screening showed good positive result with Candida albicans, Salmonella typhii, Pseudomonas aeruginosa and Escherichia coli. Cell viability assay; MTT; showed a significant cytotoxicity to MDA-MB-231 and U-87 MG human cancer cell line compared to NIH/3T3 standard embryonic fibroblast cell lines of mouse.
\end{abstract}

Keywords: Antioxidant, IC50, ZOI (Zone of Inbibition), MTT, Phytochemicals

\section{INTRODUCTION}

Medicinal plants have been used for centuries before the advent of the orthodox medicine. Plants still constitute one of the major sources of drugs in modern as well as traditional medicine throughout the world [1]. Plants show enormous versatility in synthesizing complex materials are retired to as secondary metabolites [2], could be of therapeutic significance in many areas of medicine. Dietary constituents along with plant secondary metabolites viz., flavonoids, phenolic and glucosinolate compounds have been explored for significant antioxidant and anticarcinogenic properties $[3,4]$.

In fact increased efforts are being made to isolate bioactive products from medicinal plants for their possible utility in cancer treatment. Natural products now have been contemplated of exceptional value in the development of effective anticancer drugs with minimum host cell toxicity $[5,6]$.

\footnotetext{
${ }^{*}$ Corresponding author:

Bhupal Govinda Shrestha

Department of Biotechnology, Kathmandu University, Dhulikhel, 6250, Nepal

E-mail: bgs@ku.edu.np
}

The investigation of anti-tumor agents from natural resources has been greatly emphasized in order to find useful drugs for medical treatment of human malignancies, including solid tumors [7]. It has been proposed that sequential use of cytotoxic agents could improve the anti-cancer therapy by inhibiting tumor cell proliferation and phenotypic diversification [8]. Over $50 \%$ of the drugs in clinical trials for antitumor activity were isolated from natural sources or are related to them [9].

Among the 7,000 species of medicinal plants recognized all over the world, more than 900 types of precious medicinal plants are said to be found in Nepal [10]. Among it, Berberis aristata L. (Berberidaceae), Daruharidra in Sanskrit, chutro in Nepali, a native of the high altitude Himalayan region, is traditionally used in India and Nepal to accelerate the process of wound healing. Its use in the management of infected wounds has also been described in Ayurvedic classical texts [11]. Antimicrobial properties of berberine and of berberine bearing plants have been evaluated and these were found to exhibit good activity against the Acquired Immune Deficiency Syndrome (AIDS) related opportunistic pathogens Candida albicans, Cryptococcus neoformans and Mycobacterium 
intracellularae [12]. Berberine hydrochloride was also found to exhibit significant activity against the fungi Candida albicans, C. tropicalis and $C$. glabrata [13]. There is also a solitary report of the antibacterial activity of $B$. asiatica in-vivo, another species of the genus Berberis [14]. In view of nature of this work, it was planned to examine the in vitro antibacterial activity of methanolic crude preparations of the stem bark of B. aristita along with the antioxidant property and anticancer effect, with an objective of substantiating the validity of its traditional use.

\section{MATERIALS AND METHODS}

\section{Sample preparation}

$B$. aristata stem were collected from Daman and was identified by botanist Prof. Dr. Rana B. Chettri at Kathmandu University, Dhulikhel, Nepal. The stem was washed thoroughly with tap water and shade dried at room temperature (24$26^{\circ} \mathrm{C}$ ) and then pulverized by a mechanical grinder. The powder was then passed through a 40-mesh sieve and stored in a well closed vessel until use.

\section{Solvent Extraction}

Methanol extraction or warm extraction was done using Soxhlet apparatus. 5 gram of the crushed sample along with $200 \mathrm{ml}$ of methanol was put into the soxhlet apparatus. The soxhlet was run for 28 hours at $65^{\circ} \mathrm{C}$. The methanol extract was taken from the soxhlet apparatus and green pigment was removed using Hexane in the separating funnel. The methanol fraction was then dried using rotary evaporator and various concentrations were made dissolving in Dimethyl Sulfoxide (DMSO).

\section{Phytochemical Screening}

Various Phytochemical Screening tests were done to find the presence of the active chemical constituents such as alkaloids, glycosides, terpenoids and steroids, flavonoids, reducing sugar and tannin by the standard procedure [15, 16, 17, 18]. Protocols are described shortly as mentioned below.

\section{Test for reducing sugars (Fehling's test)}

Equal volume of Fehling $\mathrm{A}$ and Fehling $\mathrm{B}$ reagents were mixed together and $2 \mathrm{ml}$ of it was added to crude extract and gently boiled. A brick red precipitate appeared at the bottom of the test tube indicated the presence of reducing sugars.

\section{Test for glycoside}

$4 \mathrm{ml}$ of extract solution was dried till $2 \mathrm{ml}$. To it was added 1-2 $\mathrm{ml}$ of Ammonium hydroxide and shaken. Appearance of cherish red color indicates the presence of glycosides.

\section{Salkowski's test}

Crude extract was mixed with $2 \mathrm{ml}$ of chloroform. Then $2 \mathrm{ml}$ of concentrated $\mathrm{H}_{2} \mathrm{SO}_{4}$ was added carefully and shaken gently. A reddish brown color indicated the presence of steroidal ring, i.e., glycone portion of the glycoside.

\section{Keller-Kilani test}

Crude extract was mixed with $2 \mathrm{ml}$ of glacial acetic acid containing 1-2 drops of $2 \%$ solution of $\mathrm{FeCl}_{3}$. The mixture was then poured into another test tube containing $2 \mathrm{ml}$ of concentrated $\mathrm{H}_{2} \mathrm{SO}_{4}$. A brown ring at the interface indicated the presence of cardiac glycosides.

\section{Test for polyphenols and tannins}

Crude extract was mixed with $2 \mathrm{ml}$ of $2 \%$ solution of $\mathrm{FeCl}_{3}$. A blue-green or blue- black coloration indicated the presence of polyphenols and tannins.

\section{Test for flavonoids}

Crude extract was mixed with few fragments of magnesium ribbon and concentrated $\mathrm{HCl}$ was added drop wise. Pink or magneta red colour appeared after few minutes which indicated the presence of flavonoids.

\section{Test for saponins}

Crude extract was mixed with $5 \mathrm{ml}$ of distilled water in a test tube and it was shaken vigorously for 30 seconds. The formation of stable foam (1 $\mathrm{cm}$ height) even after 30 minutes was taken as an indication for the presence of saponins.

\section{Test for steroids}

Crude extract was mixed with $2 \mathrm{ml}$ of chloroform and concentrated $\mathrm{H}_{2} \mathrm{SO}_{4}$ was added sidewise. A red colour produced in the lower chloroform layer indicated the presence of steroids. Another test was performed by mixing crude extract with $2 \mathrm{ml}$ of chloroform. Then $2 \mathrm{ml}$ of each of concentrated $\mathrm{H}_{2} \mathrm{SO}_{4}$ and acetic acid were poured into the mixture. The development of a greenish coloration indicated the presence of steroids.

\section{Test for terpenoids}

Crude extract was dissolved in $2 \mathrm{ml}$ of chloroform and evaporated to dryness. To this, 
$2 \mathrm{ml}$ of concentrated $\mathrm{H}_{2} \mathrm{SO}_{4}$ was added; a reddish brown coloration at the interface indicated the presence of terpenoids.

\section{Test for alkaloids}

Crude extract was mixed with $2 \mathrm{ml}$ of $1 \% \mathrm{HCl}$ and heated gently. Mayer's and Wagner's reagents were then added to the mixture. Turbidity of the resulting precipitate was taken as evidence for the presence of alkaloids.

\section{Test for coumarins}

Extract solution is concentrated to yield a residue. Dissolve residue in hot water. After cooling divide solution in two test tubes. To one test tube add 10\% (w/v) Ammonium hydroxide. Other test tube is used as control. Fluorescence color indicates the presence of coumarins.

\section{Antioxidant Assay \\ Diphenyl-2-picrylhydrazyl (DPPH) radical scavenging activity}

Extract was mixed with $160 \mu \mathrm{mol}$ L-1 DPPH in methanol. After $20 \mathrm{~min}$ incubation at room temperature in the dark, the absorbance was read at $517 \mathrm{~nm}$. Methanol was used as blank and DPPH solution without extract, as control [19]. The inhibitory percentage of DPPH ( $\%$ scavenging activity) was calculated as:

$$
\text { (A0-A1)/A0x100 }
$$

A0: absorbance of control

A1: absorbance of the sample

\section{Hydrogen peroxide scavenging assay}

Hydrogen peroxide scavenging assay is an assay for the determination of antioxidant activity of compounds by their ability to scavenge the oxidant hydrogen peroxide. A solution of hydrogen peroxide $\left(40 \mathrm{mmol} \mathrm{L}^{-1}\right)$ was prepared in phosphate buffer $\left(40 \mathrm{mmol} \mathrm{L}^{-1}, \mathrm{pH}\right.$ 7.4). Plant extracts at various concentrations were added to a hydrogen peroxide solution (40 mmol $\left.\mathrm{L}^{-1}\right)$. The absorbance of the reaction mixture was recorded at $230 \mathrm{~nm}$. The blank solution contained phosphate buffer without hydrogen peroxide. The percentage of hydrogen peroxide scavenged by the plant extract was calculated as follows [20].

Percentage of scavenged:

$$
\mathrm{H}_{2} \mathrm{O}_{2}=(\mathrm{A} 0-\mathrm{A} 1) / \mathrm{A} 0 \times 100
$$

A0: Absorbance of control

A1: Absorbance in the presence of plant extract

\section{Reducing power activity}

Reducing power activity was determined by the $\mathrm{K}_{3} \mathrm{Fe}\left(\mathrm{CN}_{6}\right) \mathrm{FeCl}_{3}$ method [21]. Each test sample was mixed with $200 \mathrm{mmol} \mathrm{L}^{-1}$ phosphate buffer ( $\mathrm{pH}$ 6.6) and 1\% Potassium Ferricyanide $\left(\mathrm{K}_{3} \mathrm{Fe}\left(\mathrm{CN}_{6}\right)\right.$. The mixture was incubated at 37 ${ }^{\circ} \mathrm{C}$ for $20 \mathrm{~min}$. An equal volume of $10 \%$ trichloroacetic acid was added to the mixture, the mixture was centrifuged at $3000 \mathrm{rpm}$ for $10 \mathrm{~min}$. The supernatant was mixed with deionized water and $0.1 \%$ Ferric Chloride $\left(\mathrm{FeCl}_{3}\right)$ at a ratio of 1 : 1: 2 . The resulting absorbance was measured at $700 \mathrm{~nm}$. Increased absorbance of the reaction mixture indicated reducing power.

\section{Antimicrobial Screening}

Antibacterial and antifungal activities were tested using Disc diffusion method. Fungal strain Candida albicans, and other bacterial strains Pseudomonas aeruginosa, Klebsiella pneumonia, Salmonella typhii, Stapbylococcus aureus, Escherichia coli were subjected to sensitivity test. Whatman Filter 1 disc $(6 \mathrm{~mm})$, was dipped in extract of various concentrations and introduced on the upper layer of the seeded agar plate with microbial concentration equivalent to $\mathrm{Mc}$ Forland unit 1. Standard antibiotic disc Chloramphenicol $30 \mathrm{mcg}$ and Nistatin $30 \mathrm{mcg}$ were used for bacterial strain and fungal strain respectively. The plates were incubated overnight at $37^{\circ} \mathrm{C}$. Microbial growth inhibition was determined by measuring the diameter of zone of inhibition [22, 23]. Results are expressed as average of triplicates.

\section{MTT Assay}

The MTT assay is a test of metabolic competence based upon assessment of mitochondrial performance, relying on the conversion of a yellow dye 3-(4,5-dimethyl-2thiazolyl)-2,5-diphenyl-2H-tetrazolium bromide (MTT) to the purple formazan derivative by mitochondrial succinate dehydrogenase in viable cells [24]. The cell lines; standard embryonic fibroblast cell lines of mouse (NIH/3T3), breast cancer cell line (MDA-MB-231) and brain tumor cell line (U-87 MG); were incubated with MEM medium, supplemented with $10 \%$ fetal calf serum, $2 \mathrm{mM}$ glutamine, $100 \mathrm{U} / \mathrm{mL}$ streptomycin and $100 \mathrm{U} / \mathrm{mL}$ penicillin at $37^{\circ} \mathrm{C}$ with $5 \% \mathrm{CO} 2$. For experiments, cells were plated in 12-well plates. After $24 \mathrm{hr}$, the extracts dissolved in 
DMSO were added. Cells were also treated with DMSO only in amount equivalent to that of extracts and control consisted of only media. At the end of $72 \mathrm{hr}$ incubation, the medium in each well was replaced by fresh medium containing $0.5 \mathrm{mg} / \mathrm{mL}$ of MTT. Three hours later, the formazan product of MTT reduction was dissolved in Isopropanol, and absorbance was measured using a Spectrophotometer. The effect of extracts was determined as the percentage of reduced dye in the control samples at $570 \mathrm{~nm}$ $[24,25]$. Results are expressed as average of triplicates.

\section{RESULTS AND DISCUSSION}

The result from phytochemical screening of Methanolic extract showed high amount of alkaloid. The percentage of total crude alkaloid is $2.45 \%$ and one of the active constituentsberberine; a major alkaloids; calculated through HPTLC densitometric method was $3.55 \%$. and tannin $0.935 \%$ [26]. Other phytochemicals like steroids, flavonoids, coumarin and terpenoids are also present in trace amount (Table 1). The major alkaloid of the plant has been reported to be berberine [27] is a well-known isoquinoline alkaloid isolated from Berberis, that are commonly used in the herbal medicine in China and in other Asian countries for the treatment of patients with gastrointestinal disorders, and as an antibiotic [28, 29]. Experimental observation declared that the plant extract were sensitive against $C$ Albicans, $S$ typhii, $P$ aeruginosa and $E$ coli, while it didn't show any activity against $K$ pneumonia, $S$ aureus (Table 2). In tissue-cultured cell assays tannins have shown antiviral, antibacterial and antiparasitic effects $[30,31,32]$. DPPH radical scavenging is considered a good in-vitro model widely used to assess antioxidant efficacy within a very short time.

The DPPH free radical scavenging of antioxidants is due to their hydrogen donating ability, the plants with higher hydrogen donating

Table 1. Result of Phytochemical screening of $B$ aristita.

\begin{tabular}{|lclc|}
\hline Phytochemicals & Presence & Phytochemicals & Presence \\
\hline Alkaloids & +++++ & Reducing Sugar & + \\
Coumarin & ++ & Saponin & + \\
Flavonoids & + & Steroids & ++ \\
Glycosides & + & Tanin & + \\
Polyphenol & + & Tri terpenoids & + \\
\hline
\end{tabular}

(-) denotes absence and $(+,++,+++)$ denotes presence in increasing order by visual observation of experiment.

Table 2: Antimicrobial Screening

\begin{tabular}{|c|c|c|c|c|c|}
\hline \multirow[b]{2}{*}{ Microorganism } & \multicolumn{4}{|c|}{ Extract (ZOI in mm) } & \multirow[t]{2}{*}{ Standard } \\
\hline & $20 \mathrm{mg} / \mathrm{ml}$ & $15 \mathrm{mg} / \mathrm{ml}$ & $10 \mathrm{mg} / \mathrm{ml}$ & $5 \mathrm{mg} / \mathrm{ml}$ & \\
\hline C. Albicans & 12 & 11.5 & 10 & 9 & 18 \\
\hline P. aeruginosa & 7 & - & - & - & 13 \\
\hline K. pneumoniae & - & - & - & - & 15 \\
\hline S. typhii & 11 & 9 & 7.5 & 6.5 & 26 \\
\hline S. aureus & - & - & - & - & 23 \\
\hline E. coli & 14 & 11 & 7 & - & 21 \\
\hline
\end{tabular}

donating capacity have shown higher DPPH free radical scavenging activity [33]. The scavenging activity on DPPH radical of $B$. aristita have 33.31 $\mu \mathrm{g} / \mathrm{ml}$ IC50 value compared to standard i.3. L
Ascorbic acid IC50 is $9.6 \mu \mathrm{g} / \mathrm{ml}$ (Figure 1). Hydrogen peroxide $\left(\mathrm{H}_{2} \mathrm{O}_{2}\right)$ is highly important because of its ability to penetrate biological membranes. $\mathrm{H}_{2} \mathrm{O}_{2}$ itself is not very reactive, but 
it can sometimes be toxic to cell because it may give rise to hydroxyl radical in the cells [34]. The results showed that $B$. aristita have an effective $\mathrm{H}_{2} \mathrm{O}_{2}$ scavenging activity. The percentage scavenging activity on hydrogen peroxide radical is $81.8 \%$ of extract at the concentration of 100 $\mu \mathrm{g} / \mathrm{mL}$. This result is similar to that of $\mathrm{L}$ Ascorbic Acid standard showing inhibition percentage $86.7 \%$. IC50 for L Ascorbic acid is $54.23 \mu \mathrm{g} / \mathrm{ml}$ and that of B. aristita is $60.6 \mu \mathrm{g} / \mathrm{ml}$ (Figure 1b).

The reducing ability of a compound generally depends on the presence of reductants which have been exhibited antioxidative potential by breaking the free radical chain, donating a hydrogen atom [35]. The plant extract reduces mostly $\mathrm{Fe}^{3+}$ ions, in a concentrated dependentmanner. The high reducing power is the high absorbance at $700 \mathrm{~nm}$. Reducing power is compared with L-Ascorbic Acid (Figure 1c). MTT Assay showed significant cytotoxicity to breast cancer cell line (MDA-MB-231) and brain tumor cell line (U-87 MG) in comparison to mouse embryo fibroblast cell line.
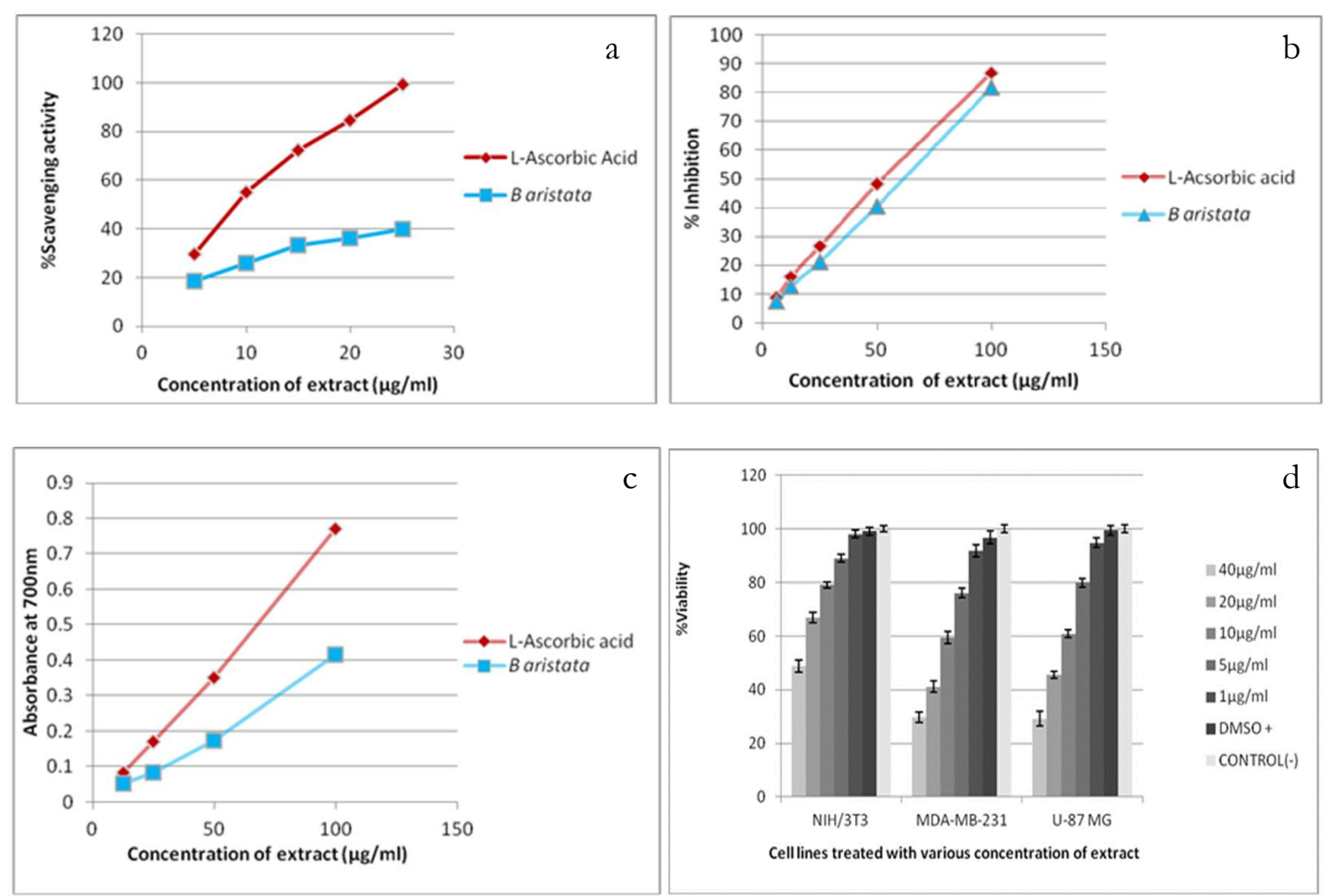

Figure 1. (a) DPPH radical scavenging activity of B. Aristita as compared with L Ascorbic Acid. (b) Hydrogen peroxide scavenging activity of B. Aristita as compared with L-Ascorbic Acid. (c) Reducing power of B. Aristita at different concentrations as compared with L-Ascorbic Acid.(d) Cells were treated with different concentrations of B. Aristita for $72 \mathrm{hr}$.

For both MDA-MB-231 and U-87 MG cancer cell line the cell viability at extract concentration $40 \mu \mathrm{g}$ is almost half of NIH/3T3 ie at that concentration cell viability forNIH/3T3 is $50 \%$ while that for the two cancercell lines is arround $25 \%$ only and there is differ ence in other extract concen-trations also (Figure 1d) which shows that the plant has anti cancer activity. This cell death on extract treatment can be correlated to mechanism of action of the highly aromatic nearly planar quaternary structure of berberine attributed to its ability to intercalate with
DNA. intercalation in combination with the inhibition of protein biosynthesis (which is the major mode of action of berberine) could be responsible for the observed cytotoxic effect [36]. Previous research also demonstrated that berberine is selectively accumulated by mitochondria on K1735-M2 melanoma cells, arresting cell proliferation, causing mitochondrial fragmentation and depolarization, oxidative stress and a decrease in ATP levels. A decrease in the number of mitochondria-like structures and in mitochondrial DNA copy num- 
ber was also found [37]. The work by Barretoet al. also confirmed the relevance of positively charges on the selective accumulation of alkaloids in mitochondria [38]. Work of some authors showed that berberine brings about aggregation of DNA and induction of apoptosis and displays antitumor activity against human and rat malignant brain tumor cells [39, 40]. Other authors found that berberine inhibits the synthesis of DNA and reverse transcriptase, while Krishnan reported that it inhibits topoisomerases I and II [41, 42].

\section{CONCLUSION}

We have been able to show that the stem bark of $B$ aristata, contains different compounds that have health benefits. The amount of alkaloids is high, as expected, because the plant is reported to have berberine, a major plant alkaloid. The plant extract also showed antifungal and antibacterial activity against major pathogens. Also, the extract showed antioxidant activity comparable to that of $\mathrm{L}$ Ascorbic Acid and in correlation to previous research conducted, our results elucidate $B$. aristata has potential anticancer properties and a detailed investigation is suggested.

\section{ACKNOWLEDGEMENTS}

We would like to acknowledge Molecular Oncology Laboratory, University of Santiago de Compostela, Spain for providing cell line and International Foundation for Science (IFS), Sweden, for providing grant to accomplish this research.

\section{REFERENCES}

1. Suri RK, Chaudhari DC, Jaffer R (1992) Commercially important medicinal plants from forest. J Ecol Bot Phytochem. 3(2): 129-140.

2. Malathi R, Ahamed John S, Cholarajan A (2012) Antioxidant Activity of Extract from the Leaves of Tylophora asthmatic. Journal of Microbiology and Antimicrobials. 4(4): 70-73

3. Sanjib B (2011) Natural Antimutagens: A Review. Research Journal of Medicinal Plant. 5(2): 116-126.

4. Li Z, Zhou LZ, Miao HZ, Lin LP, Feng HJ, Tong LJ, Ding J, Li YC (2009) Design and Synthesis of Novel C14-Hydroxyl Substituted Triptolide Derivatives as Potential Selective Antitumor Agents. J. Med. Chem. 52: 51155123.
5. Khoobchandani M, Bansal P, Medhe S, Ganesh N, Srivastava MM (2012) Antioxidant and Antimutagenic Activities of Isothiocyanates Rich Seed Oil of Eruca sativa Plant. Springer-Verlag Berlin Heidelberg. 47-51

6. Tang W, Hem I, Bertram B (2003) Antimicrobial and Antioxidant Activities of three Mentha Species Essential Oils. Planta Med. 69: 97-108.

7. Chapuis JC, Sordat B, Hostetmann K (1998) Screening for cytotoxicity of plant used in traditional medicine. J Ethnopharmacol. 23(2-3): 273-284.

8. Lotan R, Nicholson GL (1997) Can anti-cancer therapy be improved by sequential use of cytotoxic and cytostatic agents to suppress tumor cell phenotypic diversification? Biochem Pharmacol. 37(2): 3138-3140.

9. Cragg GM, Newman DJ (2000) Antineoplastic agents from natural sources: achievements and future directions. Expert Opinion on Investigational Drugs. 9: 1-15.

10. Manandhar NP (2000) Plants and People of Nepal. USA: Timber Press. 50, ISBN: 0-88192-527-6.

11. Bhandari DK, Nath G, Ray AB, Tewari PV (2000) Antimicrobial Activity Of Crude Extracts From Berberis Asiatica Stem Bark. Pharmaceutical Biology. 38 (4): 254-257.

12. Okunde AL, Hufford CD, Richardson MD, Peterson JR, Clark AM (1994) Antimicrobial properties of alkaloids from Xanthorbiza simplicissima. J Pharm Sci 83: 404-406.

13. Nakamoto K, Sadamori S, Hamda T (1990) Effects of crude drugs and berberine hydrochloride on the activities of fungi. J Prosthet Dent. 64:691-694.

14. Hashmi K, Hafiz A (1986) In-vivo antibacterial activity of Berberis asiatica. J Pakistan Med Assoc. 36:5-7.

15. Sofowra A (1993) Medicinal Plants and Traditional Medicine in Africa. Spectrum Books Ltd., Ibadan, Nigeria. 191-289.ISBN: 0-471-10367-5

16. Trease GE, Evans WC (1989) Pharmacognosy. London: Bailliere Tindall. 11:45-50. ISBN 978-07020-2934-9

17. Harborne JB (1973) Phytochemicals Methods. London: Chapman and Hall Ltd. 49-188. ISBN 0412-25550-2.

18. Chhetri HP, Yogol NS, Sherchan J, K.C. A, Mansoor S, Thapa P (2008) Phytochemical and antimicrobial evaluations of some medicinal plants of Nepal, Kathmandu University Journal of Science, Engineering and Technology. 1: 49-54.

19. Chinthamony AR, Paramasivam R, Dominic S, Muthaiyan AR, Velliyur KG (2012) Evaluation of in vitro antioxidant and anticancer activity of Alpinia purpurata, Chinese Journal of Natural Medicines. 10(4): 0263-0268.

20. Ruch RJ, Cheng SJ, Klaunig JE (1989) Prevention of cytotoxicity and inhibition of intracellular communication by antioxidant catechins isolated from Chinese green tea. Carcinogenesis. 10(6): 1003-1008. 
21. Duh PD, Yen GC, Yen WJ (2001) Antioxidant effects of water extracts from barley (Hordeum Vulgare L.) prepared under different roasting temperatures. J Agric Food Chem. 49(3): 14551463.

22. Parekh I, Chanda SV (2007) In vitro Antimicrobial Activity and Phytochemical Analysis of Some Indian Medicinal Plants. Turk J Biol. 31: 53-58.

23. Vishnoi SP, Ghosh AK, Debnath B, Samanta S, Gayen S, Jha T (2007) Antibacterial activity of Abies webbiana. Fitoterapia. 78:153-155.

24. Kviecinskia MR, Felipe KB, Schoenfelder T, Lemos LPW, Rossi MH, Goncalez E, Felicio JD, Filho DW, Pedrosa RC. Study of the antitumor potential of Bidens pilosa (Asteraceae) used in Brazilian folk medicine (2008) Journal of Ethnopharma-cology. 117: 69-75.

25. Mosmann T (1983) Rapid Colorimetric Assay for Cellular Growth and Survival: Application to Proliferation and Cytotoxicity Assays. Journal of lmmunological Methods. 65: 55-63.

26. Srivastava S, Rawat AKS (2013) Quality evaluation of Ayurvedic crude drug Daruharidra, its allied species and commercial samples from herbal drug markets of India. Evidence-Based Complementary and Alternative Medicine, Article ID 472973

27. Bhakuni DS, Shoeb A, Polpi SP (1968) Studies in Medicinal Plants: Part 1-Chemical Constituents of Berberis asiatica Roxb. Indian Journal of Chemistry. 6: 123.

28. Iwasa K, Kim HS, Watanabe Y, Lee D (1998a) Antimalaric activity and structure activity relationships of protoberberine alkaloid. Eur.J.Med.Chem. 33: 65-69.

29. Iwasa K, Nanba H, Lee D, Kang SL (1998b) Structure activity relationships of protoberberine having antimicrobial activity. Planta Med. 64: 748751.

30. Lü L, Liu SW, Jiang SB, Wu SG (2004) Tannin inhibits HIV-1 entry by targeting gp41. Acta Pharmacol. Sin. 25(2): 8.

31. Akiyama H, Fujii $\mathrm{K}$, Yamasaki O, Oono $\mathrm{T}$, Iwatsuki K (2001) Antibacterial action of several tannins against Staphylococcus aureus. J. Antimicrob. Chemother. 48(4): 91

32. Kolodziej H, Kiderlen AF (2005) Antileishmanial activity and immune modulatory effects of tannins and related compounds on_Leishmania_parasitised RAW 264.7 cells. Phytochemistry. 66(17): 71.

33. Chen CW, Ho CT (1994) Antioxidant properties of polyphenols extracted from green and black teas. J Food Lipids. 2(1): 35-46.

34. Ebrahimzadeh MA, Nabavi SF, Nabavi SM (2009) Antioxidant activities of methanol extract of Sambucus ebulus L. flower. Pak J Biol Sci. 12(5): 447450.

35. Arulmozhi S, Papiya MM, Purnima A, Sathiya N (2008) In vitro antioxidant and free radical scavenging activity of Alstonia scholaris L. Iran J Pharmacol Therapeut. 6(2):191-196.
36. Merschjohann K, Sporer F, Steverding D, Wink M (2001) In vitro effect of alkaloids on bloodstream forms of Trypanosoma brucei and T. conglolense. Planta Med. 67: 623-627.

37. Pereira GC, Branco AF, Matos JA, Pereira S.L, Parke D, Perkins EL, Serafim TL, Sardao VA, Santos MS, Moreno AJ (2007) Mitochondrially targeted effects of berberine [Natural Yellow 18, 5,6-dihydro-9,10dimethoxybenzo(g)-1,3-benzodioxolo(5,6-a) quinolizinium] on K1735-M2 mouse melanoma cells: Comparison with direct effects on isolated mitochondrial fractions. J. Pharmacol. Exp. Ther. 323: 636-649.

38. Barreto MC, Pinto RE, Arrabaca JD, Pavao ML (2003) Inhibition of mouse liver respiration by Chelidonium majus isoquinoline alkaloids, Toxicol Lett. 146: 37-47.

39. Zhank RX, Dougherty DV, Rosenblum ML (1990) Laboratory studies of berberine used alone and in combination with 1,3-bis(2-chloro- ethyl)- Initrosourea to treat malignant brain tumors. Brit.Med.J. 103: 658-665.

40. Anis KV, Kuttan G, Kuttan R (1999) Role of berberine as an adjuvant response modifier during tumor therapy in mice. Pharm. Pharmacol. Communica-tion. 5: 697-700.

41. Schmeller T, Latz-broning B, Wink M (1997) Biochemical activities of berberine, palmatine and sanguinarine mediating chemical defence against microorganisms and herbivores. Phytoche-mistry. 44: 257-266.

42. Krishnan P, Bastow KF (2000) The 9-position in berberine analogs is an important determinant of DNA topoisomerase II inhibition. Anti-Cancer Drug Des. 15: 255-264. 